\title{
Nursing protocol in vascular trauma prevention: peripheral catheterization bundle in urgency
}

\author{
Protocolo de enfermagem na prevenção de trauma vascular: bundle de cateterismo periférico em urgência
}

Protocolo de enfermería en la prevención del trauma vascular: bundle de cateterismo periférico en emergencias

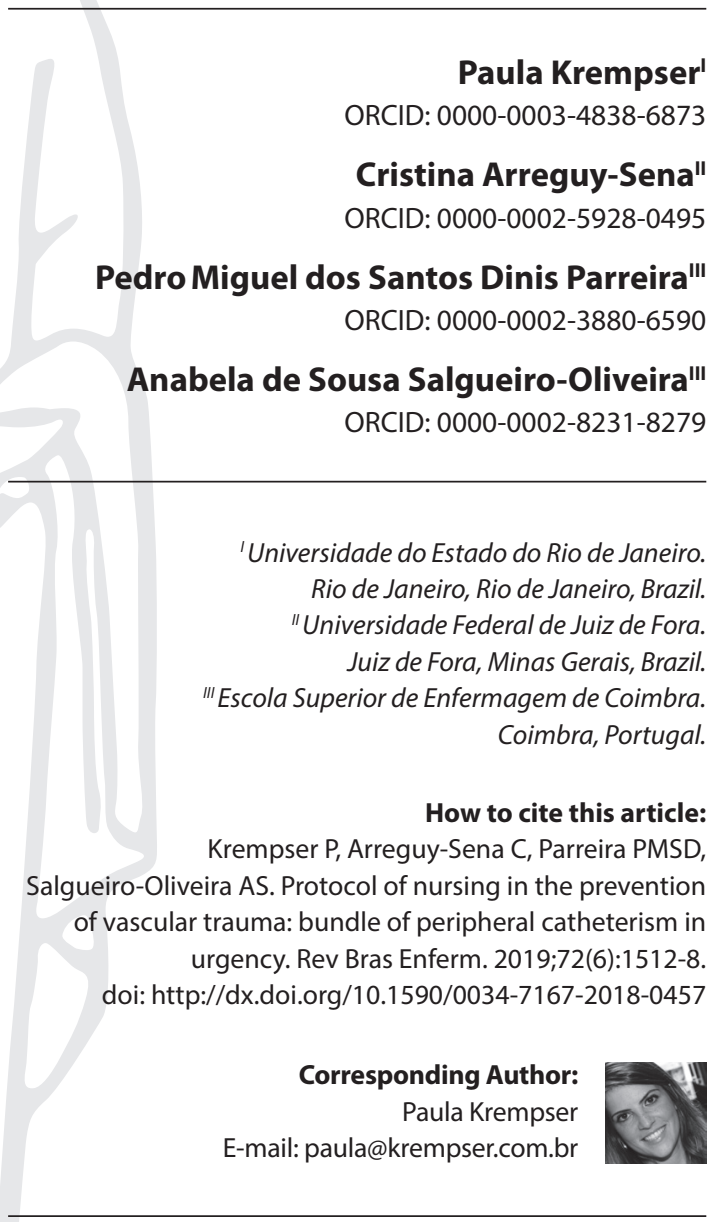

Submission: 06-08-2018 Approval: 05-21-2019

\section{ABSTRACT}

Objective: to create, apply and analyze in clinical practice the effectiveness of a bundle to prevent peripheral vascular trauma to approach the peripheral venous puncture process. Method: action research with 435 adult participants in an emergency service from 2011 to 2013. Creation of the bundle for prevention of vascular trauma based on scientific evidence, ease of operation, observation and measurement with implantation through an educational intervention of the team of nursing. Effectiveness analyzed by descriptive and inferential statistics using chi-square. Consecutive sample with $95 \%$ confidence interval. Results: Five stages of the bundle were related to the catheter fixation, permanence and removal process. The incidence of vascular traumas due to vein punctures reduced by $46.41 \%$ after implantation of the bundle to prevent vascular trauma associated with emergency peripheral catheterization. Conclusion: The bundle in clinical practice reduced vascular traumas by venipuncture.

Descriptors: Protocols; Catheterization, Peripheral; Nursing; Nursing Care; Wounds and Injuries.

\section{RESUMO}

Objetivo: criar e aplicar um bundle na prática clínica e analisar sua efetividade para prevenção de trauma vascular periférico para abordagem do processo de punção venosa periférica. Método: pesquisa-ação com 435 participantes adultos num serviço de urgência, no período de 2011 a 2013. Criação do bundle para prevenção de trauma vascular baseada em evidências científicas, com facilidade de operacionalização, observação, mensuração e implantação por meio de uma intervenção educativa da equipe de enfermagem. Efetividade analisada por estatística descritiva e inferencial, usando o qui-quadrado. Amostra consecutiva com intervalo de confiança de $95 \%$. Resultados: foram realizadas cinco etapas do bundle relacionadas ao processo de fixação, permanência e remoção do cateter. Houve redução de $46,41 \%$ na incidência de traumas vasculares após a implantação do bundle para prevenção de trauma vascular associado ao cateterismo periférico em urgência. Conclusão: o bundle, na prática clínica, reduziu a ocorrência de traumas vasculares decorrentes de punção venosa.

Descritores: Protocolos; Cateterismo Periférico; Enfermagem; Cuidados de Enfermagem; Ferimentos e Lesões.

\section{RESUMEN}

Objetivo: crear, aplicar y analizar en la práctica clínica la efectividad de un paquete para prevenir el traumatismo vascular periférico para abordar el proceso de punción venosa periférica. Método: investigación de acción con 435 participantes adultos en un servicio de emergencia de 2011 a 2013. Creación del paquete para la prevención de traumas vasculares basado en evidencia científica, facilidad de operación, observación y medición con implantación a través de una intervención educativa del equipo de enfermería. Efectividad analizada mediante estadística descriptiva e inferencial utilizando chi-cuadrado. Muestra consecutiva con intervalo de confianza del $95 \%$. Resultados: Cinco etapas del paquete se relacionaron con la fijación del catéter, la permanencia y el proceso de extracción. La incidencia de traumas vasculares se redujo en un $46,41 \%$ después de la implantación del haz para prevenir traumatismos vasculares asociados con cateterismo. Conclusión: el paquete en la práctica clínica redujo los traumas vasculares por venopunción.

Descriptores: Protocolos; Cateterismo Periférico; Enfermería; Atención de Enfermería; Heridas y Lesiones. 


\section{INTRODUCTION}

Blood vessel punctures in urgency services aim to meet the therapeutic requirements of required flow/minute infusion, availability of pathway for medication, and readiness in the effect of pharmacological conducts. However, they may trigger peripheral vascular trauma (PVT) ${ }^{(1-2)}$, lesions related to the presence of catheter and/or infused solutions that occur directly in the vessel or adjacent area, triggered by the therapeutic/diagnostic indications, users' conditions, situations/circumstances of vulnerability or technical/technological equipment used ${ }^{(2-4)}$.

These lesions are manifested by pain, alteration in sensitivity, color, temperature and integrity of the skin, in the functionality of the body structure, or in a combination of these clinical evidence ${ }^{(2-5)}$.

Nurses should work in the peripheral vessel puncture process in all stages, from installation of intravascular catheter, maintenance and permeability for therapeutic purposes, removal and care after removal, which includes the preventive/rehabilitatory form by monitoring the use of vessels and the emergence of initial manifestations of PVT. In addition, they should also work in the ongoing diagnosis or vulnerabilities tracing stage, therapeutic interventions and evaluation of nursing outcomes until the total remission of PVT manifestations ${ }^{(6-9)}$.

The bundles, based on scientific evidence, are considered a group of simple and inexpensive interventions related to a care process to address iatrogenies. Such interventions, when carried out in conjunction, result in a better clinical outcome than when implemented individually. Thus, the conduct of this research is justified by directing these interventions to the peripheral vessel puncture process, because its implementation may favor the improvement of the quality of the nursing care directed to the user served and the management of nursing work processes ${ }^{(10-11)}$.

Moreover, the research is justified because there are gaps in knowledge about the subject and also by the following arguments: 1) The peripheral venous puncture process is a routine procedure of the nursing team; 2) Peripheral vascular trauma constitutes one of the research targets for nurses with the aim of improving care for users so as to reduce incidence; 3 ) The need to reorient the work of nurses as to a routine procedure of their practice that involves the performance of the nursing team; and 4) The need to redirect the nurses' practice in the permanent education of their team, from the perspective of human resources training and commitment of their team as to education and training based on technical-scientific foundations that enhance the quality of the professional practice.

\section{OBJECTIVE}

Creation and application of a bundle in clinical practice for prevention of peripheral vascular trauma to approach the peripheral venous puncture process in urgency service and analyze its effectiveness by comparing the incidence of vascular trauma before and after an educational intervention.

\section{METHOD}

\section{Ethical aspects}

This study met all ethical and legal requirements of research involving human beings as per the legislation of the National Health
Council on research involving human beings in Brazil. The projects of the first and second steps of the research were submitted to and approved by the Ethics Committee on Research with Human Beings of the Federal University of Juiz de Fora (CEP/UFJF) under opinions number 285 of December 20, 2010 and number 172,984 of December 13, 2012. All participants were included as study subjects after acceptance and signing of the informed consent form.

\section{Study design, location, and period}

Action research conducted in an urgency and emergency service of the Unified Health System (SUS) in a city of Minas Gerais, Brazil, in the period from 2011 to 2013.

This study was carried out in three steps, namely: 1) analysis of the incidence of vascular trauma resulting from peripheral venous puncture; 2) construction, dissemination of the bundle by educational process with the nursing team and its adoption in the institutional procedures of the sector; and 3) analysis of the post-bundle incidence of trauma.

\section{Population, inclusion criteria, and exclusion criteria}

People with the following characteristics participated in the research: subjects aged over 18 years; with varied sociodemographic characteristics; Glasgow score $\geq 14$; with first puncture of each half in the upper limbs performed by the team of the female or male observation sector; whose puncture was monitored daily for the variables of interest until hospital discharge or intravascular catheter removal with no PVT manifestation observed.

Potential participants were excluded because: the intravascular catheter was not fixed; they had been punctured in the Mobile Urgency Care Service; the service user was illiterate and no legal representative was present to authorize their participation.

There were 244 users participating in the pre-bundle step and 191 in the bundle implementation phase. The research hypothesis was that the bundle implementation could reduce by $30 \%$ the occurrence of PVT resulting from nursing practice. This research had a consecutive sample provided for 435 people after loss replacement with sample estimation using confidence interval $(\mathrm{Cl})=95 \%$, relative risk $(R R)=0.30$, and exposed/unexposed ratio $=58.6 \%$.

\section{Study protocol}

In the first step of the investigation, the peripheral venous puncture process was evaluated according to the institutional protocols in force at the time; in the second step, we created a bundle for prevention of vascular traumas resulting from peripheral catheterization for the specificities of the sector under research; and in the third step, the peripheral venous puncture process was evaluated after the bundle contents were integrated into the institutional protocol in the sector.

The data collection instrument for evaluation of the venous puncture process was structured into: 1 ) characterization of the participants; 2 ) determination and measurement of the intervening variables of interest (possible factors triggering the installation of peripheral vascular trauma); 3) determination of the outcome variable (vascular trauma); and 4) photographic record of the ongoing trauma. 
The educational intervention carried out with the nursing teams addressing the bundle content constituted the second step of the investigation. It contributed to the restructuring of the nursing conducts in the peripheral venous puncture process in the institutional protocol. The seasonality criterion (March to June) was met in the first and third steps of the research to ensure similarity in the profile of participants and maintenance of the professionals during the data collection process. As the peripheral vessel puncture process evaluation stages occurred at different times, the participants were unaware of the modification in the institutional protocol, constituting the only alternative at the time.

The criteria for the creation of the "Bundle for prevention of vascular trauma associated with peripheral catheterization in urgency" were structured as follows $\left.{ }^{(12)}: 1\right)$ number of interventions $\leq 5 ; 2$ ) independence between the interventions so as not to compromise the set; 3 ) joint implementation; 4) easy execution and introduction into clinical practice to the point of ensuring confidence in its execution; 5) low operating cost; 6) no hierarchization of interventions as to level of importance; 7) intervention selection based on vascular trauma evidence traced in the first cohort study; 8) compliance with the recommendations established by the Infusion Nurses Society (INS) infusion therapy: standards of practice ${ }^{(9)}$.

\section{Analysis of results and statistics}

The data were consolidated in the program Statistical Package for the Social Sciences (SPSS) version 20.0 and analyzed by descriptive and inferential statistics.

\section{RESULTS}

Based on the context of the institutional routine of the urgency and emergency service investigated for the peripheral venous puncture process, 244 and 191 punctures were evaluated in the first and third steps of the investigation, respectively. The participants were sociodemographically characterized as follows: $68.1 \%$ were men; $40.7 \%$ had brown self-declared skin color; average age of 48.21 years (variability from 18 to 96 years of age); average of 2.6 days of hospitalization (variability from less than 24 hours to 34 days); and discharge due to improvement of the institution's users in $50.3 \%$ of the cases.

Based on the incidence and manifestations of peripheral vascular traumas traced in the first step of the investigation, we could establish a connection with potential triggering factors and interventions that could be adopted in the nursing team practice.

\section{Strategies for construction of the "Bundle for prevention of vascular trauma associated with peripheral catheteriza- tion in urgency"}

The clinical and theoretical reasoning for the construction of the "Bundle for prevention of vascular trauma associated with peripheral catheterization in urgency" was based on: tracing and incidence of PVT manifestations in the first step of the investigation; analysis of trauma manifestations relative to triggering factors and selection of nursing interventions based on scientific evidence to treat and prevent traced traumas, directing them to the care profile of the urgency/emergency sector investigated to the point of its application being feasible.

Chart 1 - Construction of the "Bundle for prevention of vascular trauma associated with peripheral catheterization in urgency", Juiz de Fora, Minas Gerais, Brazil, 2013

\begin{tabular}{|c|c|c|c|}
\hline $\begin{array}{l}\text { Manifestation } \\
\text { of periph- } \\
\text { eral vascular } \\
\text { trauma }\end{array}$ & Possible causes of the installation of peripheral vascular trauma & $\begin{array}{l}\text { Nursing interventions to } \\
\text { prevent peripheral vascular } \\
\text { trauma and their justifica- } \\
\text { tion }\end{array}$ & $\begin{array}{l}\text { Interventions } \\
\text { compatible } \\
\text { with the sec- } \\
\text { tor/profile } \\
\text { investigated }\end{array}$ \\
\hline \multirow{7}{*}{ Pain } & Venous puncture near nerves & \multirow{13}{*}{$\begin{array}{l}\text { a. Prefer puncture in basilic vein } \\
\text { in distal region } \\
\text { (In situations of urgency, user } \\
\text { condition, and/or bed location } \\
\text { this is not always applicable) } \\
\text { b. Salinize the peripheral vascu- } \\
\text { lar catheter with } 10 \mathrm{~mL} \text { of saline } \\
\text { solution (0.9\%), if incompatible } \\
\text { with the infused drug, } 5 \% \text { dex- } \\
\text { trose followed by saline, after } \\
\text { each drug infusion } \\
\text { (Drugs used in the sector are not } \\
\text { incompatible with } 0.9 \% \text { saline) } \\
\text { c. Install motion restriction splint } \\
\text { if joint puncture is the best } \\
\text { choice. } \\
\text { (Suitable material unavailable in } \\
\text { the sector) } \\
\text { d. Catheter removal without } \\
\text { angulation in relation to inser- } \\
\text { tion site } \\
\text { e. Aspirate the catheter to evalu- } \\
\text { ate positive return before drug } \\
\text { infusion }\end{array}$} & \multirow{13}{*}{$\begin{array}{l}\text { 1. Fixate the } \\
\text { catheter with } \\
\text { transparent and } \\
\text { sterile dressing } \\
\text { and extensor } \\
\text { laterally to inser- } \\
\text { tion site. } \\
\text { 2. Aspirate the } \\
\text { catheter to eval- } \\
\text { uate positive } \\
\text { return before } \\
\text { drug infusion } \\
\text { 3. Salinize the } \\
\text { peripheral } \\
\text { vascular cath- } \\
\text { eter with } 10 \text { mL } \\
\text { of } 0.9 \% \text { saline } \\
\text { after each drug } \\
\text { infusion } \\
\text { 4. Catheter } \\
\text { removal without } \\
\text { angulation in } \\
\text { relation to inser- } \\
\text { tion site }\end{array}$} \\
\hline & Vesicant/irritating drug infusion in the blood vessel & & \\
\hline & $\begin{array}{l}\text { Catheter contact with blood vessel intima due to: punctures in joints or in small- } \\
\text { caliber vessels and flexion of the punctured limb for prolonged periods }\end{array}$ & & \\
\hline & Extravasation of IV solutions (blood or drug) to subcutaneous tissue & & \\
\hline & Infusion volume/minute rate incompatible with vessel diameter & & \\
\hline & Onset of inflammatory/infectious process & & \\
\hline & Catheter displacement after venous puncture due to incorrect fixation & & \\
\hline \multirow{4}{*}{ Erythema } & $\begin{array}{l}\text { Infusion and maintained contact of vesicant or highly irritating drug inside } \\
\text { the blood vessel. }\end{array}$ & & \\
\hline & Venous infusion speed & & \\
\hline & Onset of inflammatory/infectious process & & \\
\hline & Catheter displacement after venous puncture due to incorrect fixation & & \\
\hline \multirow[t]{2}{*}{ Edema } & $\begin{array}{l}\text { Transfixation of the vein during vascular puncture, fixation or due to move- } \\
\text { ment of the punctured limb }\end{array}$ & & \\
\hline & Catheter displacement after venous puncture due to incorrect fixation & & \\
\hline
\end{tabular}




\begin{tabular}{|c|c|c|c|}
\hline $\begin{array}{l}\text { Manifestation } \\
\text { of periph- } \\
\text { eral vascular } \\
\text { trauma }\end{array}$ & Possible causes of the installation of peripheral vascular trauma & $\begin{array}{l}\text { Nursing interventions to } \\
\text { prevent peripheral vascular } \\
\text { trauma and their justifica- } \\
\text { tion }\end{array}$ & $\begin{array}{l}\text { Interventions } \\
\text { compatible } \\
\text { with the sec- } \\
\text { tor/profile } \\
\text { investigated }\end{array}$ \\
\hline \multirow{3}{*}{$\begin{array}{l}\text { Ecchymosis or } \\
\text { hematoma }\end{array}$} & Reduction of vascular circulation by fixation strangling the punctured limb & \multirow{9}{*}{$\begin{array}{l}\text { f. Catheter fixation with } \\
\text { transparent and sterile dress- } \\
\text { ing and extensor laterally to } \\
\text { insertion site. } \\
\text { g. Perform finger pressure to } \\
\text { the puncture site after remov- } \\
\text { ing the catheter from the } \\
\text { inside of the blood vessel for a } \\
\text { period of eight minutes. }\end{array}$} & \multirow{9}{*}{$\begin{array}{l}\text { 5. Perform } \\
\text { finger pressure } \\
\text { at puncture site } \\
\text { after catheter } \\
\text { removal from } \\
\text { the inside of } \\
\text { the vessel for } \\
\text { eight minutes or } \\
\text { longer time in } \\
\text { cases of coagu- } \\
\text { lation alteration }\end{array}$} \\
\hline & Transfixation of the blood vessel & & \\
\hline & Blood spill to subcutaneous tissue due to non-hemostasis of the vessel & & \\
\hline $\begin{array}{l}\text { Continuity } \\
\text { solution }\end{array}$ & $\begin{array}{l}\text { Catheter movement inside the blood vessel due to movement of the punc- } \\
\text { tured limb }\end{array}$ & & \\
\hline \multirow{2}{*}{ Induratum } & Consequence of the extravasation of drugs to the subcutaneous tissue & & \\
\hline & Concentration of the infused drug & & \\
\hline \multirow{2}{*}{$\begin{array}{l}\text { Alteration } \\
\text { in local tem- } \\
\text { perature }\end{array}$} & $\begin{array}{l}\text { Consequence of infectious process installation due to failure in aseptic } \\
\text { technique }\end{array}$ & & \\
\hline & $\begin{array}{l}\text { Catheter displacement after venous puncture due to incorrect fixation or } \\
\text { vein transfixation with consequent extravasation of infusions }\end{array}$ & & \\
\hline Secretion & $\begin{array}{l}\text { Consequence of infectious process installation due to failure in aseptic } \\
\text { technique }\end{array}$ & & \\
\hline
\end{tabular}

Chart 1 shows the contents of the construction of this bundle, implemented in the male and female observation sectors of an urgency service.

\section{Implementation of the "Bundle for prevention of vascu- lar trauma associated with peripheral catheterization in urgency" in clinical practice}

After the creation of the "Bundle for prevention of vascular trauma associated with peripheral catheterization in urgency," there was previous scheduling with the nursing teams of the sectors of all service shifts with small groups of up to four nurses, nursing technicians, and nursing assistants. On this occasion, there was the presentation of the PVT incidence rates recorded in the sectors investigated by means of photograph of the types of manifestations and the way to prevent them through the adoption of the bundle items.

The elements of the bundle were demonstrated in the order of their implementation with the help of the didactic resource of a video showing the execution to facilitate the understanding followed by the individual repetition until the doubts were clarified and the initial skill was acquired. The bundle interventions were incorporated into the institutional routine as a common practice for all the users of the sectors investigated in the second stage of the research, making available the material necessary for its implementation.

The"Bundle for prevention of vascular trauma associated with peripheral catheterization in urgency" was based on five steps, namely: 1) fixating the catheter with transparent and sterile dressing and extensor laterally to insertion site; 2) aspirating the catheter to evaluate positive return before drug infusion; 3 ) Salinizing the peripheral vascular catheter with $10 \mathrm{~mL}$ of $0.9 \%$ saline after each drug infusion; 4) removing the catheter without angulation in relation to insertion site; 5) performing finger pressure at the puncture site after removing the catheter from the inside of the vessel for eight minutes or longer time in cases of coagulation alteration.

\section{Effectiveness of the "Bundle for prevention of vascular trauma associated with peripheral catheterization in urgency"}

In a total of 435 peripheral venous punctures monitored, 143 occurrences of PVT were found before the institutional protocol was changed, that is, $58.6 \%$ of the peripheral venous punctures evaluated presented at least some type of PVT and, after the bundle was adopted, there was a decrease to $31.4 \%$ of PVT.

There was the possibility of each participant presenting more than one manifestation of peripheral vascular trauma in the same puncture site and/or adjacent areas, which led to higher frequency of manifestations than the total number of traumas found, that is, a participant that had the outcome of vascular trauma determined may have presented more than one manifestation of trauma concomitantly.

The vascular trauma manifestation incidence pre- and postbundle implementation and the Chi-square value $\left(X^{2}\right)$ were used to determine the bundle efficacy significance (Table 1).

With the adoption of the bundle, we observed a reduction in the incidence of vascular trauma at a higher rate than that predicted in the hypothesis to be tested (30\%), and percentages above $50 \%$ were observed in almost all PVT manifestations resulting from peripheral venous puncture, confirmed by significant $X^{2}$ values, below 0.05

The evidence of vascular trauma manifestations identified in the first cohort when analyzed in the light of the results obtained after the implementation of the bundles allowed to identify some risk factors for the nursing diagnosis entitled "Risk for vascular trauma" of the NANDA International Taxonomy, namely: 1) reaffirmation of known vulnerability: inadequate available insertion site; 2) pointed out by the present investigation: instability of the 
intravascular catheter fixation process; digit time pressure after removal of the intravascular catheter and antisepsis pre-installation of the catheter and 3) which needs to be further investigated in subsequent studies: flushing $\mathrm{x}$ drug dilution process.

Table 1 - Comparison of the peripheral vascular trauma manifestations traced in the venous puncture process, before and after the implementation of the "Bundle for prevention of vascular trauma associated with peripheral catheterization in urgency", Juiz de Fora, Minas Gerais, Brazil, 2013

\begin{tabular}{|c|c|c|c|c|c|}
\hline \multirow{2}{*}{$\begin{array}{l}\text { Possible types of trauma } \\
\text { manifestations }\end{array}$} & \multicolumn{2}{|c|}{ Pre bundle } & \multicolumn{2}{|c|}{ Post bundle } & \multirow{2}{*}{$X^{2}$} \\
\hline & $\mathbf{n}$ & $\%$ & $\mathbf{n}$ & $\%$ & \\
\hline \multicolumn{6}{|l|}{ Pain } \\
\hline Catheter insertion site & 103 & 42.2 & 41 & 21.5 & 0.000 \\
\hline Venous path & 61 & 25 & 22 & 11.5 & 0.014 \\
\hline \multicolumn{6}{|l|}{ Skin color change } \\
\hline Ecchymosis & 21 & 8.6 & 3 & 1.6 & 0.000 \\
\hline Hematoma & 3 & 1.2 & 4 & 2.1 & 0.475 \\
\hline Localized erythema & 11 & 4.4 & 0 & 0 & - \\
\hline Path erythema & 22 & 9.1 & 12 & 6.1 & 0.000 \\
\hline Functional capacity & 17 & 7 & 3 & 1.6 & 0.164 \\
\hline \multicolumn{6}{|l|}{ Edema } \\
\hline Catheter insertion site & 37 & 15.2 & 4 & 2.1 & 0.000 \\
\hline Widespread & 14 & 5.7 & 5 & 2.6 & 0.328 \\
\hline Godet signal & 8 & 3.2 & 1 & 0.5 & 0.164 \\
\hline \multicolumn{6}{|l|}{ Induratum } \\
\hline General & 2 & 0.8 & 0 & 0 & - \\
\hline In the venous path & 33 & 13.5 & 13 & 6.8 & 0.014 \\
\hline \multicolumn{6}{|l|}{ Continuity solution } \\
\hline Larger than catheter diameter & 31 & 12.7 & 7 & 3.7 & 0.000 \\
\hline Localized (catheter site) & 30 & 12.3 & 6 & 3.1 & 0.000 \\
\hline Secretion & 2 & 0.8 & 2 & 1 & 0.629 \\
\hline \multicolumn{6}{|l|}{ Altered temperature } \\
\hline Altered temperature & 25 & 10.2 & 2 & 1 & 0.001 \\
\hline Total punctures with Trauma & 143 & 58.6 & 60 & 31.4 & 0.000 \\
\hline
\end{tabular}

Adherence to the "Bundle for prevention of vascular trauma associated with peripheral catheterization in urgency" enabled showing quality in nursing care also by facilitating the visualization of the venous catheter insertion site and its adjacent areas, as shown in Figure 1.

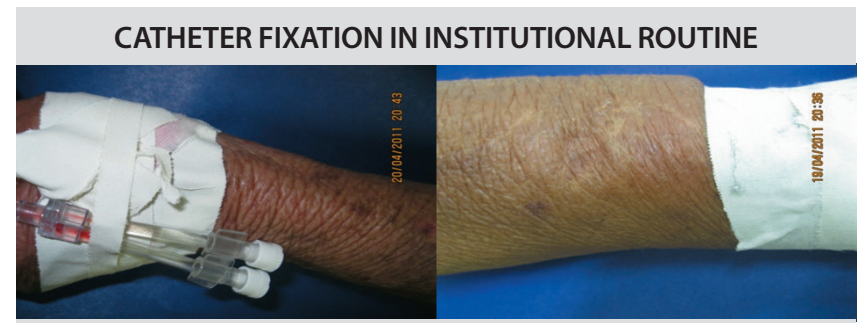

CATHETER FIXATION AFTER BUNDLE IMPLANTATION

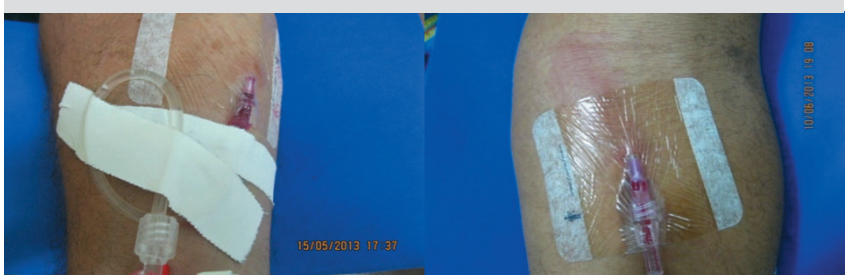

Figure 1 - Image of intravenous catheter fixation in the institutional routine and after implementation of the "Bundle for prevention of vascular trauma associated with peripheral catheterization in urgency", Juiz de Fora, Minas Gerais, Brazil, 2013
Accordingly, the care service protocol to guide the professional's conduct in clinical practice, when supported by (inter)national scientific evidence, has positive impacts on the care provided to people who have their veins punctured for therapeutic purposes.

The impact of the results was limited by the research scenario, as well as by the participants' short length of stay in the observation sector where they were being monitored.

\section{DISCUSSION}

According to the Infusion Therapy Standards of Practice, nurses must have continued competence, apply knowledge and decision-making skills in the practice of infusional therapy and adhere to the introduction of new equipment and technologies ${ }^{(9)}$.

Thus, similarly to the recommendations of other bundles, whose implementation resulted in significantly reduced incidence of nosocomial infections considered acceptable and not preventable ${ }^{(13-16)}$, the groups were encouraged to adhere to the changes in the peripheral vessel puncture process through motivating initiatives, determination of being consistent with scientific evidence, reaffirmation of the reasons that substantiated each recommendation (backed validation), and approach based on dialogue of trust for each proposed element, highlighting the importance for improving the quality of nursing care and consequent reduction of iatrogenesis for the patient ${ }^{(17)}$.

Of the 17 PVT manifestations, only for two - hematoma and secretion presence at puncture site - there was no reduction in incidence, which may be justified because these manifestations are not susceptible to reduction only by the nursing interventions implemented. This finding constitutes a limit of the present investigation, because some intervention activities initially prepared were not applicable in a simple way considering the institutional profile of care service $e^{(2,4,9)}$.

The use of transparent film, as one of the stages of the bundle, brings as advantages to the traditional fixation process: favoring the visualization and monitoring of the fixation complex, catheter insertion site, and adjacent areas; ensuring the effectiveness of gas exchanges of the skin at the place of its positioning and water impermeability; reducing the number of dressing changes, and the team's working time; and preventing local contamination by exposure to pathogens ${ }^{(1,8-9,18)}$. The film is considered a technology compatible with its incorporation into nursing practice grounded on scientific evidence ${ }^{(19-21)}$.

The use of flushing is also a component present in the bundle, whose purpose is based on reducing drug interaction, on ensuring the accuracy of the prescribed dosage, on preventing obstructions resulting from deposition and crystallization of drugs inside the catheter and the formation of clot inside the catheter extensor/ needle, with recommendation supported by the literature ${ }^{(22)}$.

This investigation was relevant because vascular trauma: 1) is an incident, preventable problem that can be controlled with nursing conducts that are neglected in health institutions $\mathrm{s}^{(2-4,18)} ; 2$ ) is perceived and reported by the user through physical complaints and alterations in appearance ${ }^{(2-4,19)}$; and 3) can be reduced and/or prevented by using the bundle - a low-cost strategy -, simple and easy-to-implement conducts, and is based on technical-scientific evidence with impact on clinical practice ${ }^{(9,11-12,20)}$. 
The results enabled: 1) inferring that nurses have (inter)national support to approach therapeutically the diagnosis of "risk for vascular trauma"(20); 2) reaffirming the need for nursing care to have procedural, preventive character based on scientific criteria; 3 ) early tracing cases of peripheral vascular trauma to the point of minimizing their progression and worsening; and 4) establishing an alignment between care and scientific evidence in clinical practice.

\section{Study limitations}

The study was limited by the application of the "Bundle for prevention of vascular trauma associated with peripheral catheterization in urgency" in a context that can be overcome by the replication of the study in other clinical and cultural contexts aiming to: reaffirm its effectiveness in reducing PVTs; reduce hospital costs of peripheral punctures; improve nursing care; and be used as a strategy in the educational processes of nursing professionals.

Puncture site evaluation time was a factor with direct influence on the incidence of observed vascular traumas when considering that infectious processes - such as the manifestation of secretion at the puncture site - are characterized by occurring in a longer observation time, thus being a relevant point to be considered in future studies.

Further research should be carried out in other contexts, aiming to reduce the incidence of manifestation of hematoma and presence of secretion at the puncture site, a goal that was not achieved in the present research due to the specificities of the sector, of the users in conjunction with the interventions implemented.

\section{Contributions to the area of nursing, health, or public policies}

The study's contribution to the area of nursing, health and public policies is the possibility that the bundle contributes to the health care of people who have their vessels punctured in an urgency service of public health care, leading to the adoption of best health practices aiming to prevent problems and/or reduce the most common situations of vulnerability found among users. This is a work practice based on scientific evidence.

\section{CONCLUSION}

The bundle created and applied in clinical practice for prevention of peripheral vascular trauma to approach the venous puncture process in urgency service was shown to be effective when comparing the incidence of PVT before and after the educational intervention carried out by nursing professionals, with a reduction of $46.41 \%$.

\section{ACKNOWLEDGEMENT}

We thank the nursing team of the urgency service, which participated in the educational intervention and contributed to the evaluation of a new nursing practice in the care process for users who had their veins punctured in the service. We also thank the users who participated in the data collection and enabled the evaluation of the bundle's effectiveness to prevent vascular trauma for approach of the peripheral venous puncture process in the urgency service.

\section{REFERENCES}

1. Phillips LD, Gorsk L. Manual of IV Therapeutics: evidence-based practice for infusion therapy. 6th ed. Philadelphia: FA Davis; 2014.

2. Krempser P, Arreguy-Sena C, Barbosa APS. Características definidoras de trauma vascular periférico em urgência e emergência: ocorrência e tipos. Esc Anna Nery. 2013;17(1):24-30. doi: 10.1590/S1414-81452013000100004

3. Silva RNA, Arreguy-Sena C. Survey of clinical manifestations of peripheral vascular trauma in children admitted to pediatric wards. Online Braz J Nurs. 2013;12(3):451-61. doi: 10.5935/1676-4285.20134002

4. Herdman HT, Kamitsuru S, editors. NANDA International Nursing Diagnoses: definitions \& classification 2018-2020. 11th ed. New York: Thieme; 2017

5. Lojas-Sanchez LZ, Parra I, Camargo-Figuera FA. Incidence and factors associated with development of phlebitis: results of a pilot study cohort. Rev Enf Ref. 2015;serIV(4):61-7. doi: 10.12707/RIII13141

6. Murassaki ACY, Versa GLGS, Bellucci Jr JA, Meireles VC, Vituri DW, Matsuda LM. Avaliação de cuidados na terapia intravenosa: desafio para a qualidade na enfermagem. Esc Anna Nery. 2013;17(1):11-6. doi: 10.1590/S1414-81452013000100002

7. Souza AEBR, Oliveira JLC, Dias DC, Nicola AL. Nursing care quality in peripheral intravenous therapy: analysis by indicators. Cogitare Enferm. 2014;19(3):521-7. doi: 10.5380/ce.v19i3.35808

8. Brasil. Ministério da Saúde. Agência Nacional de Vigilância Sanitária (ANVISA). Medidas de Prevenção de Infecção Relacionada à Assistência à Saúde [Internet]. Brasília; 2017 [cited 2018 Apr 22]. Available from: https://www20.anvisa.gov.br/segurancadopaciente/index.php/ publicacoes/item/caderno-5.

9. Infusion Nurses Society. Infusion therapy: standards of practice. J Infus Nurs [Internet]. 2016. [cited 2017 Sep 27];39(1S):1-169. Available from: http://source.yiboshi.com/20170417/1492425631944540325.pdf

10. Resar R, Griffin FA, Haraden C, Nolan TW. Using care bundles to improve health care quality [Internet]. Cambridge: Institute for Healthcare Improvement; 2012 [cited 2017 Sep 27]. Available from: https://emergencylaparotomy.org.uk/wp-content/uploads/2015/11/ IHIUsingCareBundlesWhitePaper2012-1.pdf

11. Kaier K, Wilson C, Hulscher M, Wollersheim H, Huis A, Borg M, et al. Implementing strategic bundles for infection prevention and 
management. Infection. 2012;40(2):225-8. doi: 10.1007/s15010-011-0186-5

12. Hunt TK, Hopf HW. Selection of bundle components. Arch Surg. 2011;146(10):1220-1. doi: 10.1001/archsurg.2011.249

13. Alroumi F, Sarwar A, Grgurich PE, Lei Y, Hudcova J, Craven DE. Strategies for prevention of ventilator-associated pneumonia: bundles, devices, and medications for improved patient outcomes. Hosp Pract. 2012;40(1):81-92. doi: 10.3810/hp.2012.02.949

14. Kalil AC, Wiener-Kronish JP. Is the evidence for benefits from ventilator-associated pneumonia bundles reliable enough for implementation in a general hospital? Crit Care Med. 2012;40(1):348-50. doi: 10.1097/CCM.0b013e318236ec24

15. National Services Scotland. Health Protection Scotland. Targeted literature review: What are the key infection prevention and control recommendations to inform a central vascular catheter (CVC) maintenance care quality improvement tool? [Internet]. Edinburgh; 2014 [cited 2017 Nov 03]. Available from: http://www.hps.scot.nhs.uk/resourcedocument.aspx?id=2792

16. Dallé J, Kuplich NM, Santos RP, Silveira DT. Infecção relacionada a cateter venoso central após a implementação de um conjunto de medidas preventivas (bundle) no Centro de Terapia Intensiva (CTI). Rev HCPA [Internet]. 2012 [cited 2018 Apr 03];32(1):10-17. Available from: https:// www.lume.ufrgs.br/bitstream/handle/10183/157902/000835245.pdf?sequence=1

17. Santos JLG, Lima MADS, Pestana AL, Garlet ER, Erdmann AL. Challenges for the management of emergency care from the perspective of nurses. Acta Paul Enferm. 2013;26(2):136-43. doi: 10.1590/S0103-21002013000200006

18. Danski MTR, Johann DA, Vayego SA, Oliveira GRL, Lind J. Complications related to the use of peripheral venous catheters: a randomized clinical trial. Acta Paul Enferm. 2016;29(1):84-92. doi: h10.1590/1982-0194201600012

19. Danski MTR, Oliveira GLR, Johann DA, Pedrolo E, Vayego SA. Incidence of local complications in peripheral venous catheters and associated risk factors. Acta Paul Enferm. 2015;28(6):517-23. doi: 10.1590/1982-0194201500087

20. Nogueira D, Cruz ICF. Risco de trauma vascular: revisão sistematizada da literature. J Specialized Nurs Care. [Internet]. 2017 [cited 2018 Apr 24];9(1). Available from: http://www.jsncare.uff.br/index.php/jsncare/article/view/2931/733

21. Krempser P, Arreguy-Sena C, Rodrigues BMRD, Braga LM, Parreira, PMSD. Evolution of the process of peripheral venipuncture and technological resources according to nursing professionals. Cienc Cuid Saude. 2017;16(3). doi: 10.4025/cienccuidsaude.v16i3.32040

22. Braga LM, Parreira PMSD, Arreguy-Sena C, Carlos DM, Mónico LSM, Henriques MAP. Incidence rate and the use of flushing in the prevention of obstructions of the peripheral venous catheter. Texto Contexto Enferm. 2018;27(4):e2810017. doi: 10.1590/0104-07072018002810017 